\title{
Pengurangan Limbah Minyak Jelantah dengan Pelatihan Pembuatan Sabun Cuci Cair Ekonomis di Kampung Sawah, Bogor
}

\author{
Awwalunisa Aliya Kusuma \\ awwalunisa.ak@gmail.com \\ UIN Walisongo Semarang
}

\begin{abstract}
Used Cooking Oil has a negative impact if it is dumped carelessly into the environment and has a positive impact if one of them is used is soap. In this study, corn cobs were used. This soap-making dedication activity aims to provide knowledge to the public regarding the economic potential of used cooking oil waste and corn cobs, skills training for the community regarding the processing of used cooking oil and corn cobs as laundry soap. The method is carried out in two stages: (a) Making soap with used cooking oil and corn cobs. Soap making is done using $\mathrm{KOH}$ as a reactant and fragrance to provide an attractive soap product. (b) Training activities for the community. Before and after training measured participants knowledge and attitudes with the questionnaire. The training activities were carried out in Kampung Sawah RW 06, attended by 16 participants. The Data analyzed univariate to see the characteristics of respondents and bivariate with a postwar test to assess the increase in knowledge and test Mc Nemar to assess the change in attitudes. There were increasing knowledge from an average of 3,52 to 4,08 $(P=0,004)$. Attitude changes also occurred before the training of positive attitudes as much as $43 \%$ to $94 \%$ after training $(P=0,021)$. The increased knowledge and attitudes that are statistic significan are expected to increase the increase in good behaviour in the processing of household waste, especially processing the waste oil and corn cobs.
\end{abstract}

Keywords: waste oil, corn cobs, soap, $\mathrm{KOH}$

\begin{abstract}
Abstrak: Minyak Jelantah berdampak negatif jika dibuang sembarangan ke lingkungan dan berdampak positif jika dimanfaatkan salah satunya adalah sabun. Pada penelitian ini digunakan limbah tongkol jagung. Kegiatan pengabdian pembuatan sabun ini bertujuan pemberian pengetahuan kepada masyarakat mengenai potensi ekonomis limbah minyak jelantah dan tongkol jagung, dan pelatihan keterampilan pada masyarakat mengenai pengolahan limbah minyak jelantah dan tongkol jagung sebagai sabun cuci. Metode yang dilakukan dalam dua tahapan: (a) Pembuatan sabun dengan minyak jelantah dan tongkol jagung. Pembuatan sabun dilakukan menggunakan $\mathrm{KOH}$ sebagai reaktan dan pewangi untuk memberikan produk sabun yang menarik. (b) Kegiatan pelatihan kepada masyarakat. Sebelum dan setelah pelatihan diukur pengetahuan dan sikap peserta dengan kuesioner. Data hasil kuesioner akan dianalisis univariate untuk melihat karakteristik responden dan bivariate dengan uji $t$ berpasangan untuk menilai peningkatan pengetahuan dan uji Mc nemar untuk menilai perubahan sikap. Kegiatan pelatihan dilakukan di Kampung Sawah RW 06 dengan diikuti 16 peserta. Pengetahuan peserta sebelum dan sesudah pelatihan meningkat dari rata-rata 3,52 menjadi 4,08 $(\mathrm{p}=0,004)$. Perubahan sikap juga terjadi dimana sebelum pelatihan sikap positif sebanyak $43 \%$ menjadi $94 \%$ setelah pelatihan $(\mathrm{p}=0,021)$. Peningkatan pengetahuan dan sikap yang signifikan ini diharapkan dapat meningkat peningkatan perilaku yang positif dalam pengolahan limbah minyak jelantah dan tongkol jagung.
\end{abstract}

Kata kunci: Minyak bekas, tongkol jagung, sabun, $\mathrm{KOH}$

\section{PENDAHULUAN}

Kampung Sawah, Kelurahan Tanah

Baru merupakan salah satu kampung padat penduduk yang ada di Kota Bogor. Jumlah

jiwa berdasarkan data di Kelurahan Tanah

Baru sebanyak 20,903 (Badan Pusat Statistik, 
2020). Angka tersebut terus meningkat setiap tahunnya. Angka tersebut berdampak pada jumlah konsumsi yang semakin meningkat. Sebagian besar masyarkat menggunakan minyak sebagai bahan primer dalam proses memasak.

Minyak goreng adalah kebutuhan pokok yang sering digunakan dalam mengolah konsumsi pangan. Minyak goreng biasanya digunakan 3 - 4 kali dalam proses penggorengan. Penggunaan minyak goreng lebih dari 4 kali, akan meningkatkan kadar asam lemak yang semakin jenuh. Ketika asam lemak jenuh dibarengi dengan proses penggorengan pada suhu tinggi dan waktu yang lama pada pemanasan, minyak goreng bekas akan semakin rusak dan berbahaya bagi kesehatan. Selain itu, minyak goreng bekas yang dibuang ke tanah akan mencemari tanah dan menyebabkan tanah tidak subur. Sedangkan apabila dibuang ke sungai akan mempengaruhi kandungan mineral pada air sungai (Kusumaningtyas et al., 2019). Minyak goreng bekas pada keadaan tersebut disebut minyak jelantah (Tomskaya et al., 2008; Wati Ibnu Hajar dan Mufidah, 2016).

Minyak Jelantah termasuk kategori limbah karena bilangan asam dan peroksidanya meningkat serta mengandung senyawa karsinogenik selama penggorengan (Yusuf, 2010). Penelitian Aminah (2010), paparan oksigen dan suhu tinggi pada minyak akan memicu reaksi oksidasi. Parameter terjadinya oksidasi pada minyak seperti free fatty acid (FFA), komponen polar, asam konjugat dienoat yang semakin meningkat pada setiap kali proses penggulangan penggorengan (Aminah, 2010). Sebenarnya, minyak jelantah dapat dimanfaatkan kembali dengan proses pemurnian, selanjutnya dapat diolah menjadi bahan baku industri non pangan seperti sabun (Wati Ibnu Hajar dan Mufidah, 2016).

Sabun tersebut dapat bernilai ekonomis dan dapat digunakan untuk keperluan mencuci serta merupakan salah satu solusi polusi dari limbah minyak jelantah. Sabun merupakan senyawa natrium atau kalium dengan asam lemak dari minyak yang berbentuk padat, lunak atau cair, dan berbusa (Ketaren, 2006). Sabun dapat dibuat dari minyak (trigliserida), asam lemak bebas (ALB) dan metil ester asam lemak dengan mereaksikan basa alkali terhadap masingmasing zat, yang dikenal dengan proses saponifikasi (Hajar et al., 2016). Sabun dihasilkan oleh proses saponifikasi, yaitu hidrolisis lemak menjadi asam lemak dan gliserol dalam kondisi basa. Pembuat kondisi basa, basa yang digunakan adalah $\mathrm{NaOH}$ maka produk reaksi berupa sabun keras (padat)(Lubis \& Mulyati, 2019) dan sesuai standar SNI (Prabowo et al., 2016), sedangkan basa yang digunakan $\mathrm{KOH}$ maka produk reaksi berupa sabun cair dengan rendemen 83,04 \% (Pratiwi, 2014) dan nilai 
stabilitas busa $50 \%$ (Bidilah et al., 2017).

Penjernihan dengan metode adsorben sebelum proses saponifikasi pada sabun banyak diteliti untuk menurunkan kadar asam lemak bebas. Metode adsorben merupakan metode altenatif karena selain pembuatan yang mudah dan sederhana, biaya yang dibutukan relatif murah. Wati dan Mufidah (2016), menjelaskan penambahan ampas tebu sebagai adsorben dapat menurunkan kadar asam lemak bebas dari $0,30 \%$ menjadi 0,15 $\%$ setelah dilakukan perendaman selama 72 jam (Wati Ibnu Hajar dan Mufidah, 2016). Penelitian Riyanta dan Nurniswati (2016), menjelaskan penggunaan karbon aktif pada metode adsorben menurunkan asam lemak bebas menjadi 50,37 \% (Riyanta dan Nurniswati, 2016). Karbon aktif adalah bahan yang banyak digunakan dan sering dipakai. Berdasarkan penelitian Kusuma, et al (2020) karbon aktif arang tongkol jagung merupakan karbon aktif yang dapat mengurangi limbah (Kusuma Aliya et al., 2020).

Penelitian ini menggunakan karbon aktif tongkol jagung sebagai adsorben untuk mengurangi asam lemak pada limbah minyak goreng. Tongkol jagung yang sudah dicuci bersih kemudian dijemur dibawah terik matahari selama 3 hari. Selanjutnya tongkol jagung diarangkan menggunakan proses pembakaran terbuka. Setelah menjadi arang tongkol jagung direndam dalam minyak jelantah selama 2 jam pada suhu $80^{\circ} \mathrm{C}$.
Berdasarkan uraian yang telah dijabarkan, maka permasalahan yang diangkat melalui kegiatan pengabdian ini adalah aspek produksi sabun cuci piring dari limbah minyak jelantah dan tongkol jagung.

\section{RUMUSAN MASALAH}

Kemukakan Permasalahan tersebut adalah:

(a) Kurangnya pengetahuan tentang manfaat limbah minyak jelantah dan tongkol jagung,

(b) Belum adanya pengetahuan dan keterampilan pembuatan sabun dari minyak jelantah dan tongkol jagung,

(c) Kurangnya kesadaran masyarakat pada proses pengendalian pencemaran air dan tanah.

Oleh karena itu, kegiatan pengabdian masyarakat ini difokuskan pada:

1) Pemberian pengetahuan kepada masyarakat mengenai potensi ekonomis limbah minyak jelantah dan tongkol jagung,

2) Pelatihan keterampilan pada masyarakat mengenai pengolahan limbah minyak jelantah dan tongkol jagung sebagai sabun cuci,

3) Pemberian informasi mengenai proses pengendalian pencemaran air dan tanah (Kusumaningtyas et al., 2019) 


\section{METODE}

Pelaksanaan ini dilakukan dalam dua tahapan: (a) Pembuatan sabun dengan minyak jelantah dan tongkol jagung. Pembuatan sabun dilakukan menggunakan $\mathrm{KOH}$ sebagai reaktan dan pewangi untuk memberikan produk sabun yang menarik. (b) Kegiatan pelatihan kepada masyarakat.

Pelatihan praktek pembuatan sabun, dilakukan di Kampung Sawah Kelurahan Tanah Baru, Kecamatan Bogor Utara, Kota Bogor dengan sasaran 15 orang. Materi panduan yang disusun berupa bahan presentasi dengan media pemaparan di Tv dan foto demonstrasi pembuatan sabun. Sebelum dan setelah pelatihan diukur pengetahuan dan sikap peserta terhadaap pengolah minyak jelantah menjadi sabun dengan kuesioner. Data hasil kuesioner akan dianalisis univariate untuk melihat karakteristik responden dan bivariatif dengan uji t berpasanagn untuk menilai peningkatan pengetahuan dan uji Mc nemar untuk menilai perubahan sikap.

\section{HASIL PEMBAHASAN}

\section{A. Pembuatan Sabun Dari Minyak Jelantah} dan Tongkol Jagung

Tahapan pertama adalah proses despicing. Minyak jelantah $500 \mathrm{~mL}$ dimasukkan ke dalam gelas ukur kemudian ditambahkan air dengan takaran $500 \mathrm{~mL}$. Setelah itu dipanaskan sampai volume air tinggal setengahnya. Proses selanjutnya yaitu pemisahan air dan minyak menggunakan botol plastik lalu dikocok, fraksi air pada bagian bawah dan fraksi minyak dibagian atas sehingga pada botol dilubangi dibawah agar air semuanya keluar, setelah itu dipisahkan minyak dari kotoran yang mengendap dengan menggunakan kain saring hingga mendapatkan minyak hasil despicing yang dituangkan ke dalam baskom.

Langkah selanjutnya proses netralisasi. Pada proses netralisasi langkah yang dilakukan yaitu membuat larutan $\mathrm{KOH}$ 15\% (15 g KOH dilarutkan di dalam 100 mL air), dan memasukkan larutan $\mathrm{KOH} 15 \%$ sebanyak $5 \mathrm{~mL} \mathrm{KOH}$ dalam $100 \mathrm{~mL}$ minyak jelantah hasil despicing. Kemudian memanaskan minyak jelantah hasil penghilangan bumbu (despicing) pada suhu $60^{\circ} \mathrm{C}$. Selanjutnya campuran diaduk selama 10 menit dan disaring dengan kain saring untuk memisahkan endapan.

Pada proses pemucatan (bleaching) prosesnya minyak jelantah hasil netralisasi sebanyak $100 \mathrm{~mL}$ ditambahkan arang tongkol jagung sebanyak 7,5 gram. Kemudian dipanaskan sampai suhu $100{ }^{\circ} \mathrm{C}$ selama 1 jam dan disaring dengan menggunakan kain saring dan didapatkan minyak hasil pemucatan.

Pada pembuatan sabun cair atau proses saponikasi konsentrasi $\mathrm{KOH}$ yang digunakan adalah 36\% (36 g KOH dilarutkan 
di dalam 100 mL air). Minyak sebanyak 100 $\mathrm{mL}$ dimasukkan ke dalam baskom dan ditambahkan dengan $\mathrm{KOH}$, volume $\mathrm{KOH} 40$ mL. Kemudian dilakukan pengadukan dan pemanasan pada suhu $100{ }^{\circ} \mathrm{C}$ yang dilakukan hingga proses saponifikasi selama 2 jam. Proses pengadukan dan pemanasan dihentikan pada saat telah terbentuk sabun lunak (wet soap) yang ditandai dengan tercapainya kondisi trace, yaitu dapat dibuat

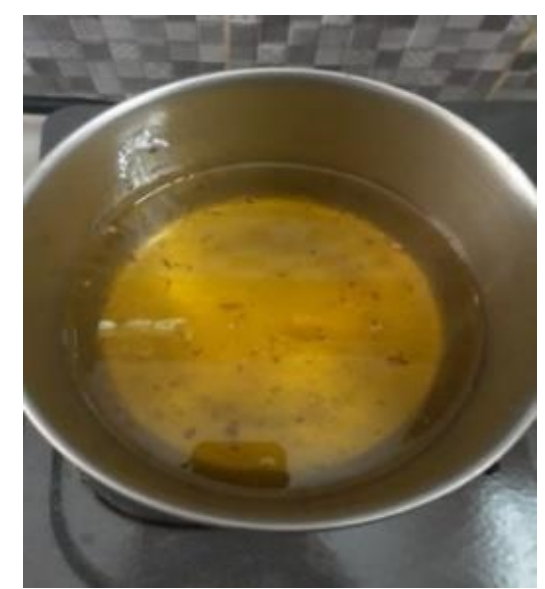

Gambar 1. Proses desciping garis di atas adonan secara nyata dan sudah tidak ada lagi minyak yang belum tersabunkan. Hasil sabun padat yang diperoleh didiamkan selama 1 hari pada suhu ruangan.

Proses selanjutnya adalah penambahan air dengan rasio air: sabun adalah 3:1. Pada proses pengenceran ini dilakukan pemanasan dengan suhu $60^{\circ} \mathrm{C}$ dan waktu 1 jam. Selanjutnya adalah memisahkan sabun cair dari kotoran yang tidak diinginkan yakni ditambahkan $1 \mathrm{ml}$ gliserol dengan cara menyaring. Setelah dilakukan penyaringan maka telah didapatkan sabun cair bersih, pada tahap ini dilakukan penambahan warna dan parfum. Pewarna maupun parfum yang ditambahkan sebesar 5mL, selanjutnya didiamkan selama 2 hari. Setelah didiamkan selama 2 hari sabun dipacking. Proses pembuatan disajikan pada gambar 1,2,3,4 dan 5.

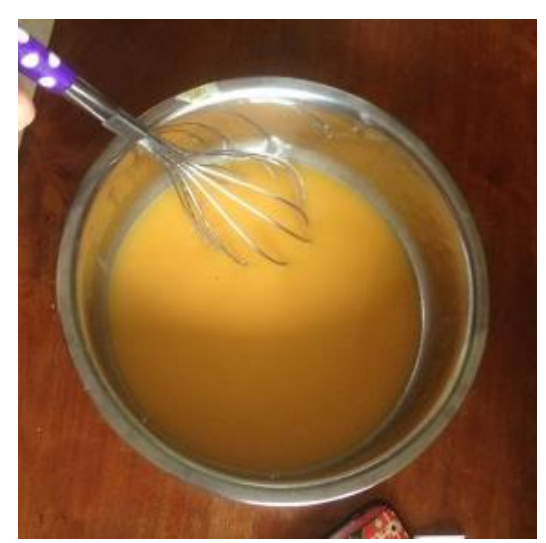

Gambar 2. Proses

Netralisasi

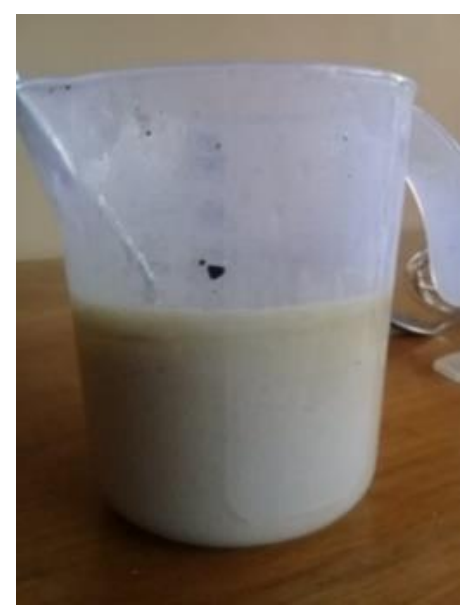

Gambar 3. Proses

Pemurnian 


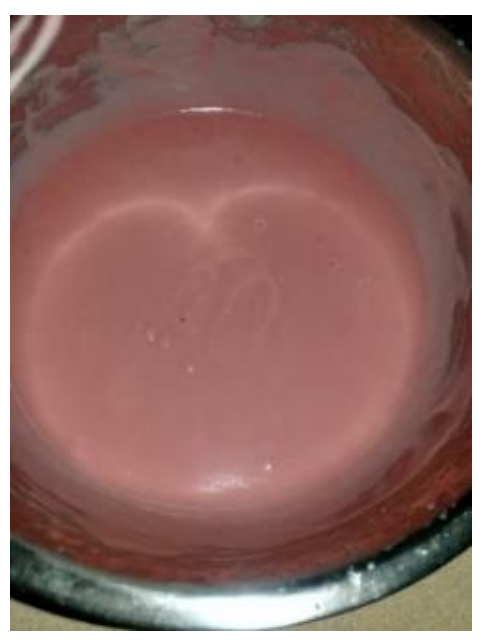

Gambar 4. Proses

Saponikasi

\section{B. Pelatihan Pembuatan Sabun Minyak}

\section{Jelantah}

Kegiatan inti pengabdian kepada masyarakat berupa pelatihan pembuatan sabun cuci piring dari minyak jelantah dan tongkol jagung telah dilaksanakan pada tanggal 25 Oktober 2020 di Rumah Peserta KKN 75 UIN Walisongo. Kegiatan diikuti oleh 16 pengurus BKM Bersatu Maju Tanah Baru dan Masyarakat Kampung Sawah RW 06. Pelatihan meliputi penjelasan, penunjukan foto dan sample pembuatan. Warga sangat antusias mendengarkan penjelasan tim pengabdi terlihat dari pertanyaan-pertanyaan yang diajukan pada saat pelatihan. Masyarakat antusias mengikuti kegiatan pengabdian karena materi yang disampaikan dapat menambah pengetahuan dan ketrampilan serta memberikan wawasan kewirausahaan. Produk dari pengabdian masyarakat berupa sabun cuci dari minyak jelantah dan tongkol jagung. Bahkan beberapa warga tertarik untuk membuatnya dirumah. Pelaksanaan kegiatan pengabdian masyarakat ini disajikan pada gambar 6,7 dan 8 .

Kegiatan penyuluhan dilakukan dengan memberikan penjelasan kepada masyarakat akan dampak negatif dari pemakaian dan pembuangan minyak jelantah sembarangan ke sungai dan tanah serta dampak positif dari minyak jelantah dan pemanfaatan limbah tongkol jagung. Penjelasan dampak negatif pemakaian minyak jelantah dari sisi kesehatan dan pembuangan limbah minyak jelantah dari sisi lingkungan serta dampak positif pemanfaatan limbah tongkol jagung. Sisi negatif dari minyak jelantah dari segi kesehatan adalah apabila minyak jelantah dipakai kembali untuk proses memasak dapat menyebabkan kanker, memicu penyakit jantung koroner, struk dan hipertensi. Efek lain yang ditimbukan dari minyak jelantah yaitu dari segi lingkungan dapat mencemari lingkungan air sungai dan mengurangi kesuburan tanah (Kusumaningtyas et al., 2019). Dampak positif penggunaan limbah minyak jelantah salah satunya adalah sabun dengan melakukan proses pemurnian dan saponikasi. Dampak positif penggunaan tongkol jagung dapat digunakan sebagai adsorben pada pembuatan sabun adalah dengan mengadsorp asam lemak yang tinggi. Sabun yang dihasilkan dari adanya proses bleaching 
jumlah busanya lebih banyak karena kadar asam lemak bebasnya semakin sedikit sehingga proses penyabunan berlangsung dengan sangat baik.

Selanjutnya pemaparan materi berupa foto proses dalam membuat sabun dari minyak jelantah dan bonggol jagung. Pemaran materi dilakukan oleh seorang Mahasiswa KKN UIN Walisongo jurusan Kimia. Pemaran meliputi semua proses pembuatan sabun dari mulai tahap despicing hingga tahap packing dan sample dari proses tersebut. Peserta pelatihan interaktif karena saat pemaparan materi banyak pertanyaan dan peserta tertarik untuk mencoba pembuatan sabun dirumah.

Setelah pemaparan materi, sesi selanjutnya adalah pembagian produk sabun atau souvenir kegiatan pelatihan ini. Peserta setelah dibagikan produk tersebut, langsung mecoba mencium produk sabun. Peserta sangat antusias ketika mencoba mencium produk souvenir karena produk tersebut tidak bau minyak.

Sesi terakhir peserta diminta mengisi kuesioner dari kegiatan pelatihan ini. Kuesioner berupa pertanyaan pelatihan meliputi sebelum dan sesudah pelatihan pembuatan sabun dan respon dari kegiatan pelatihan ini.

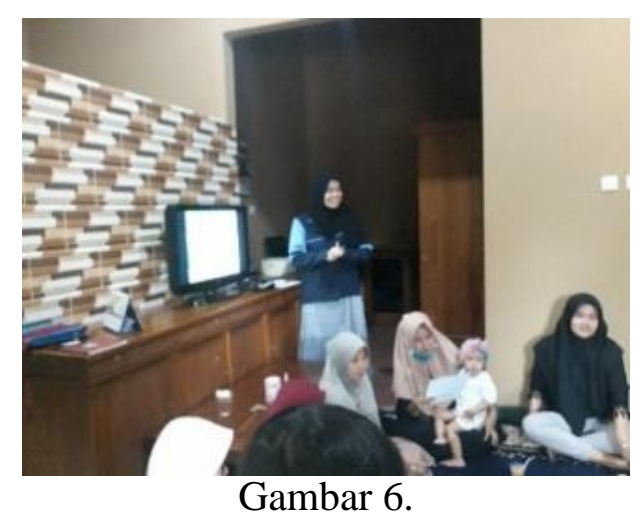

Pemapamaran materi

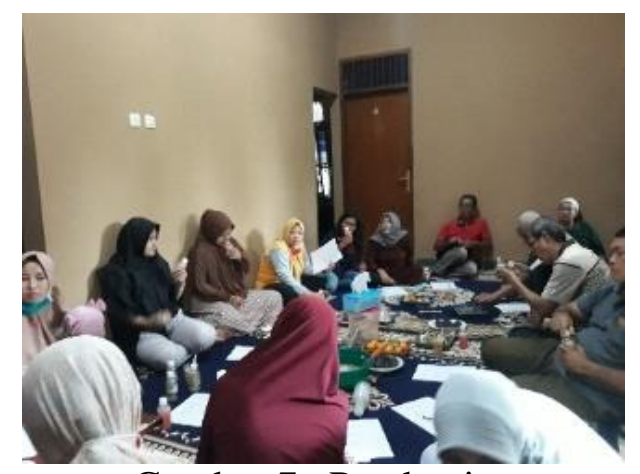

Gambar 7. Pembagian

Souvenir Sabun

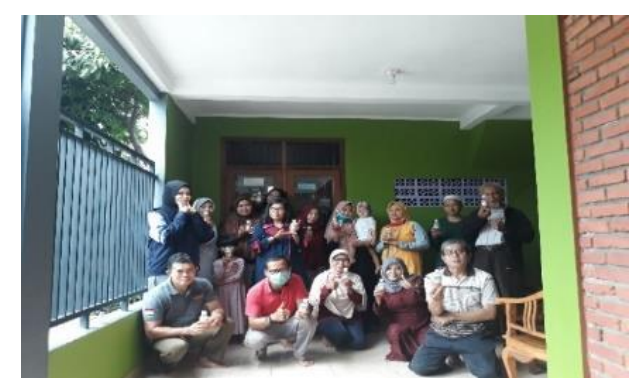

Gambar 8. Foto

Bersama dengan Peserta

\section{Karakteristik Peserta}

Peserta pelatihan terdiri dari 16 ibu dan bapak dari BKM Bersatu Maju Tanah Baru dan Masyarakat Kampung Sawah RW 06.

Tabel. 1 Karakteristik Peserta Pelatihan Pembuatan Sabun dari Minyak Jelantah dan Tongkol Jagung 


\begin{tabular}{|c|c|c|}
\hline $\begin{array}{l}\text { Keteranga } \\
\text { Umur: }\end{array}$ & $\begin{array}{l}\text { Frekuens } \\
\quad \text { i (n) }\end{array}$ & $\begin{array}{c}\text { Presentas } \\
\text { e }(\%)\end{array}$ \\
\hline$<30$ tahun & 3 & 18 \\
\hline 40-60 tahun & 13 & 82 \\
\hline Total & 16 & 100 \\
\hline Pekerjaan & & \\
\hline Pelajar & 2 & 12 \\
\hline $\begin{array}{c}\text { Ibu Rumah } \\
\text { Tangga }\end{array}$ & 11 & 68 \\
\hline Pegawai & 4 & 20 \\
\hline Total & 16 & 100 \\
\hline
\end{tabular}

Berdasarkan tabel 1. Terlihat karakteristik pada peserta pelatihan yang antusian mengikuti kegiatan adalah ibu-ibu. Hal ini dapat terjadi karena limbah minyak jelantah banyak disumbangkan dari limbah rumah tangga dan ibu -ibu lah yang menjadi pelaku utama dalam menyumbangkan limbah minyak jelantah tersebut. Ibu-ibu dapat menerapkan pelatihan ini dengan memanfaatkan limbah rumah tangganya. Sementara pelajar yang mengikuti kegiatan pelatihan ini karena penasaran akan informasi yang baru dan muktahir agar kelak kedepan dapat menerapkan dan mengembangkan inovasi penelitian ini.

\section{Pengetahuan Peserta Sebelum dan}

\section{Setelah Pelatihan}

Pengetahuan tentang pengolah minyak jelantah menjadi sabun diukur dengan menggunakan kuesioner dengan nilai 1-5 . Pengetahuan diukur sebelum dan sesudah pelatihan. Berikut adalah data hasil pengetahuan.

\section{Pengetahuan}

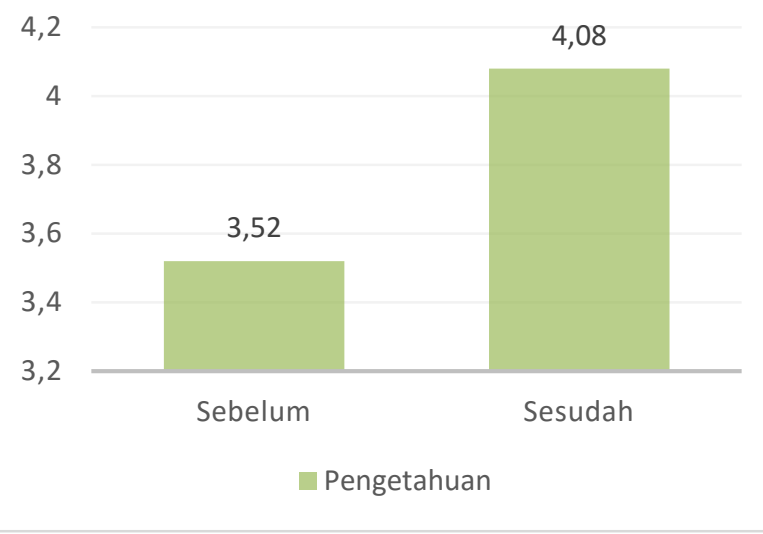

Grafik 1. Peningkatan pengetahuan tentang pengolahan minyak jelantah dan tongkol jagung menjadi sabun

Berdasarkan grafik 1 diatas terlihat bahwa ada kenaikan nilai rata-rata dari 3,52 menjadi 4,08. Peningkatan pengetahuan ini diuji dengan uji $\mathrm{t}$ berpasangan. Hasil Uji t berpasangan pengetahuan sebelum dan setelah pelatihan pembuatan sabun dari minyak jelantah dan tongkol Jagung. menunjukkan peningkatan pengetahuan sebelum dan setelah pelatihan pembuatan sabun dari minyak jelantah menunjukkan hasil yang signifikan $(p=0,004)$.

\section{E. Sikap Peserta Pelatihan}

Sikap mengenai pengolahan minyak jelantah dan tongkol jagung menjadi sabun diukur dengan menggunakan kuesioer sebelum dan setelah pelatihan, yang dikategorikan mejadi sikap positif dan sikap negatif. Berikut adalah hasil pengukuran sikap sebelum dan sesudah pelatihan. 
Tabel 2. Sikap Peserta Sebelum dan Sesudah Pelatihan

\begin{tabular}{|c|c|c|}
\hline Sikap & Sebelum & Setelah \\
\hline Positif & 7 & 15 \\
\hline Negatif & 9 & 1 \\
\hline Total & 16 & 16 \\
\hline
\end{tabular}

pelatihan adalah meningkatya jumlah peserta dengan sikap positif dianalisis dengan uji Mc Nemar seperti terlihat pada table di bawah ini.

Tabel 3. Hasil uji Mc Nemar perubahan sikap sebelum dan setelah pelatihan

\begin{tabular}{|c|c|c|c|c|}
\hline \multirow[t]{2}{*}{$\begin{array}{l}\text { Sebelum } \\
\text { Pelatihan }\end{array}$} & \multicolumn{2}{|c|}{$\begin{array}{l}\text { Setelah } \\
\text { Pelatihan }\end{array}$} & \multirow{2}{*}{\multicolumn{2}{|c|}{ Jumlah }} \\
\hline & Positif & Negatif & & \\
\hline Positif & 6 & 1 & 7 & 0,021 \\
\hline Negatif & 9 & 0 & 9 & \\
\hline Total & 15 & 1 & 16 & \\
\hline
\end{tabular}

sabun dari minyak jelantah dan tongkol jagung merupakan hal baru bagi peserta, hal ini ditunjukkan dari hasil kuesioner yang menunjukkan $20 \%$ peserta belum pernah mengetahui informasi tentang pengolahan minyak jelantah. Hal ini juga yang mendukung peningkatan pengetahuan pada $100 \%$ peserta karena peserta sangat antusias dan secara statistic menunjukkan peningkatan yang signifikan. Peningkatan pengetahaun juga didukung oleh factor pekerjaan dimana $12 \%$ pelajar, $20 \%$ pegawai dan $68 \%$ ibu rumah tangga. Hal ini sesuai dengan teori Notoatmojo yang menyatakan pengetahuan di pengaruhi oleh tingkat pekerjaan.
Sikap peserta terhadap pengolahan minyak jelantah dan tongkol jagung menjadi sabun pada awal pelatihan menunjukkan 57\% peserta memiliki sikap positif dan $43 \%$ peserta memiliki sikap negatif. Namun setelah pelatihan terjadi perubahan sikap para peserta dimana $94 \%$ peserta memiliki sikap postif sedangkan $6 \%$ peserta masih memiliki sikap negatif. Perubahan sikap setelah pelatihan juga menunjukkan perubahan yang significan secara statistik $(\mathrm{p}=0,021)$. Menurut Notoatmodjo (2007), Sikap adalah persiapan atau kemauan untuk bertindak, bukan pelaksana motif tertentu. Sikap bukanlah tindakan atau aktivitas, melainkan kecenderungan tindakan atau perilaku. Sikap ini masih merupakan respon tertutup, bukan respon terbuka terhadap perilaku terbuka (Notoatmodjo, 2007). Hal ini sejalan dengan penelitian yang dilakukan oleh Yusnita et al, (2019) yang menyatakan ada hubungan yang signifikan antara sikap dengan tindakan masyarakat dalam pengelolaan sampah domestik Harapan Mulya, Jakarta Pusat (Yusnnita et al., 2019).

Peningkatan pengetahuan dan sikap yang signifikan secara statistik diharapkan dapat meningkatkan penelitian-penelitian yang inovatif dalam pengelolaan limbah domestik, khususnya pembuangan limbah minyak goreng dan tongkol jagung. Hal ini sesuai dengan Notoatmodjo (2007) yang mengemukakan bahwa pengetahuan atau 
kognisi merupakan bidang yang sangat penting dalam pembentukan perilaku seseorang (Notoatmodjo, 2007). Menurut Hassan et al, (2011), jika masyarakat memahami pembuangan sampah sebagai responden peserta pelatihan, maka otomatis menjadi perlu untuk dikembangkan karena pada dasarnya pengelolaan sampah merupakan tindakan yang berdampak positif dalam berbagai aspek, seperti kesehatan, ekonomi dan masalah sosial (Hassan et al., 2011).

Melalui kegiatan pelatihan pembuatan sabun dari minyak jelantah, dapat membekali peserta pelatihan di Kampung Sawah, Bogor untuk memproduksi sabun cuci cair sendiri sehingga dapat menghemat pengeluaran konsumsi rumah tangga. Manfaat dari kegiatan ini, peserta pelatihan dapat berpikiran terbuka dan termotivasi untuk menggunakan keterampilan yang diperolehnya sebagai usaha sampingan atau usaha keluarga untuk membantu perekonomian keluarganya (Haro et al., 2017).

\section{SIMPULAN}

Kegiatan pengabdian kepada masyarakat ini bertujuan untuk memberikan ilmu pelatihan pengolahan minyak jelantah dan tongkol jagung menjadi sabun cuci. Proses pembuatan sabun meliputi proses despicing, netralisasi, bleaching, saponifikasi dan pencairan sabun. Hasil dari kegiatan ini adalah adanya peningkatan pengetahuan peserta mengenai pembuatan sabun yang ditunjukkan dengan rata-rata nilai dari 3,52 sebelum pelatihan menjadi 4,08 setelah pelatihan dan uji statitik menunjukkan peningkatan ini signifikan $(\mathrm{p}=0,004)$. Selain itu juga adanya perubahan sikap yang lebih postitif tentang pengolahan minyak jelantah menjadi sabun dari $43 \%$ menjadi $94 \%$ dan uji statistik menunjukkan perubahan yang signifikan $\quad(\mathrm{p}=0,021)$. Perubahan ini diharapkan dapat mengubah perilaku masyarakat dalam pengolahan limbah minyak jelantah dan tongkol jagung, serta termotivasi untuk menggunakan keterampilan sebagai usaha sampngan dalam membantu perekonimian keluarga di Kampung Sawah Kelurahan Tanah Baru, Bogor Utara.

\section{DAFTAR PUSTAKA}

Aminah, S. (2010). Bilangan Peroksida Minyak Goreng Curah Dan Sifat Organoleptik Tempe Pada Pengulangan Penggorengan. Jurnal Pangan Dan Gizi, 1(1), 115523. https://doi.org/10.26714/jpg.1.1.2010. Badan Pusat Statistik. (2020). Bogor Utara Subdistrict in Figure 2020.

Bidilah, S. A., Rumape, O., \& Mohamad, E. (2017). Optimasi Waktu Pengadukan 
dan Volume $\mathrm{KOH}$ Sabun Cair Berbahan Dasar Minyak Jelantah. Jurnal Entropi, 12(6), 55-60.

Hajar, E. W. I., Purba, A. F. W., Handayani, P., \& Mardiah. (2016). Proses Pemurnian Minyak Jelantah Menggunakan Ampas Tebu untuk Pembuatan Sabun Padat. Jurnal Integrasi Proses, 6(2), 57-63.

Hassan, Wirsal, \& Bakti, D. (2011). Hubungan karakteristik ibu rumah tangga dengan pengolahan sampah domestik dalam mewujudkan medan green and clean $(m d g c)$ di lingkungan $i$ kelurahan pulo brayan darat ii kecamatan medan timur kota medan tahun 2011.

Ketaren. (2006). Pengantar Teknologi Minyak dan Lemak Pangan. Universitas Indonesia.

Kusuma Aliya, A., Lathifaturrohmah, B., \& Dyah Lestari Erfiana, E. (2020). Pengaruh Penambahan Arang Aktif Limbah Tongkol Jagung Untuk Mengurangi Kadar Kesadahan Total. Walisongo Journal of Chemistry, 3(1), 31.

https://doi.org/10.21580/wjc.v3i1.61 28

Kusumaningtyas, R. D., Qudus, N., Rr. Dewi Artanti, P., \& Kusumawardani, R. (2019). Penerapan Teknologi
Pengolahan Limbah Minyak Goreng Bekas Menjadi Sabun Cuci Piring Untuk Pengendalian Pencemaran Dan Pemberdayaan Masyarakat. Jurnal Abdimas, 22(2), 201-208.

Lubis, J., \& Mulyati, M. (2019). Pemanfaatan Minyak Jelantah Jadi Sabun Padat. 20, 116-120.

Notoatmodjo, S. (2007). Kesehatan masyarakat ilmu \& seni. Rineka Cipta.

Prabowo, S. A., Ardhi, M. W., \& Sasono, M. (2016). Pemberdayaan Masyarakat Desa Mojopurno Melalui Pelatihan Pembuatan Sabun Dari Limbah Minyak Jelantah. Jurnal Terapan Abdimas, $\quad 1, \quad 26$. https://doi.org/10.25273/jta.v1i1.337

Pratiwi, P. (2014). Pembuatan Sabun Cuci Piring Cair Dari Minyak Goreng Bekas (Jelantah). Universitas Sebelas Maret.

Riyanta, A., \& Nurniswati. (2016). Adsorpsi Minyak Jelantah Menggunakan Karbon Aktif Dan Serbuk Kopi Pada Pembuatan Sabun Padat Ramah Lingkungan. Jurnal Senit, 9, 494-505.

Tomskaya, L. A., Makarova, N. P., \& Ryabov, V. D. (2008). Determination of the hydrocarbon composition of crude oils. Chemistry and Technology of Fuels and Oils, 44(4), 280-283. 
https://doi.org/10.1007/s10553-008-

0052-z

Wati Ibnu Hajar, E., \& Mufidah, S. (2016).

Penurunan Asam Lemak Bebas Pada

Minyak Goreng Bekas Menggunakan

Ampas Tebu Untuk Pembuatan Sabun.

Jurnal Integrasi Proses, 6(1), 22-27.

Yusnnita, Bahri, S., \& Tunru, I. S. A. (2019).
TERHADAP
PENGOLAHAN
MINYAK JELANTAH MENJADI
SABUN ( SABUN MIJE ). 25(2), 112-
116.

Yusuf, Y. (2010). Penyuluhan dan Pelatihan

Pemanfaatan Limbah Minyak Goreng

(Minyak Jelantah) Sebagai Bahan

Baku Pembuatan Sabun Cair. Warta

Pengabdian Andalas, 1, 195-206. 